\title{
Determining the Energy Efficiency of Corn, Sun- flower and Soybean Cultivation with the Use of Ridge Technology
}

\author{
Evgeny Zykin ${ }^{1,}{ }^{*}$, Vladimir Kurdyumov ${ }^{1}$, and Svetlana Lazutkina ${ }^{1}$ \\ ${ }^{1}$ Department of Agrotechnologies, Machines and Life Safety, Ulyanovsk State Agrarian University, \\ Ulyanovsk, Russia
}

\begin{abstract}
The article presents the developed energy-saving, resourcesaving ridge technology for cultivating row crops and means of mechanization for its implementation allows increasing the yield of row crops on average in 5 years up to $38 \%$ without the use of environmentally unsafe herbicides. The implementation of ridge technology to cultivate corn for grain, sunflower and soybeans, the energy efficiency coefficients, respectively, amounted to $15.54 ; 9.71$ and 3.43 units, which is by $0.6 ; 3.81$ and 4.41 units more in comparison with the traditional technology of cultivation of the aforesaid crops on a flat surface of the field.
\end{abstract}

\section{Introduction}

The reduction of material and economic costs and increase in the yield of crops grown is one of the major objectives in the implementation of agricultural technology.

To reduce the cost of energy, material, and labor resources, it is necessary to carry out agrochemical, technical, organizational, and economic measures: the introduction of crop rotation systems, the elimination of "unnecessary" technological operations, the use of economical equipment. It is important to know that the high-quality preparation of the field for planting seeds, stimulation of the root system growth and development, providing it with nutrients is the initial requirement for the introduction of any technology for cultivating row crops in food production. At the same time, mechanical tillage should preserve soil fertility and retain moisture as much as possible $[1,2,3]$.

\footnotetext{
* Corresponding author: evg-zykin@yandex.ru
} 


\section{Materials and methods}

Most modern technologies for the cultivation of row crops on a flat surface of the field involves plowing the soil in autumn or disking it to a depth of $10 \ldots 12 \mathrm{sm}$, followed by the spring harrowing of the field with tine harrows to preserve the moisture in the soil accumulated in the autumn-winter period. Then, pre-sowing cultivation, sowing, rolling and care of crops are performed.

Pre-sowing cultivation at many agricultural enterprises is carried out separately since row-crop seeders only sow seeds and roll the sowing lines. Crop care involves loosening interrow spacing with sweeps, scuffle knives and additional working bodies of various designs, or treating crops with herbicides.

To ensure the required quality of ridge technology for cultivating row crops, technological operations must be performed in the following sequence using existing and proposed mechanization means (Fig. 1).

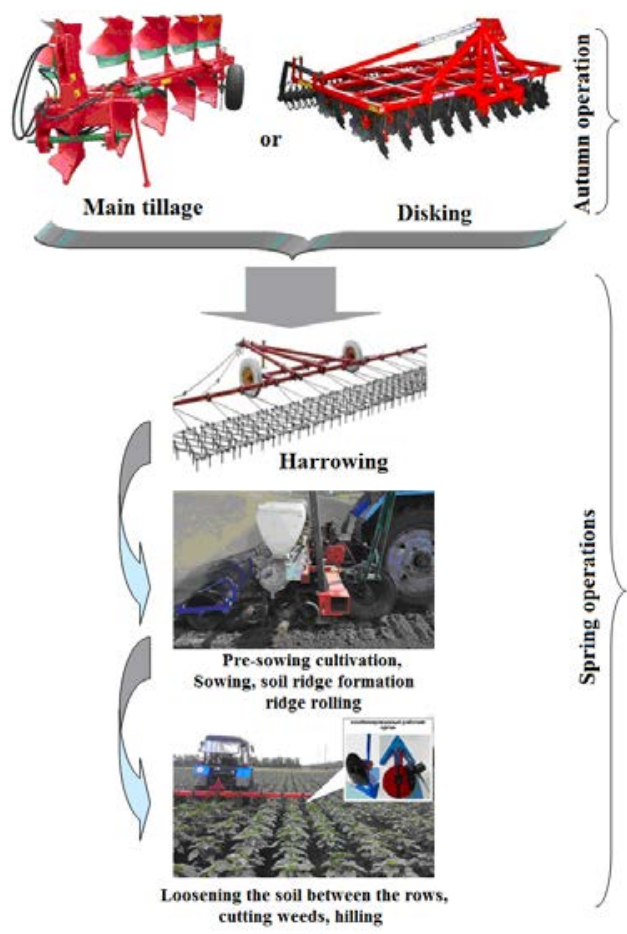

Fig. 1. Technological process of row crop cultivation

After spring harrowing (by mass-produced implements of mechanization), in conformity with the soil moisture and temperature conditions, pre-sowing cultivation is carried out 
simultaneously, sowing seeds into a moist soil layer, forming a soil ridge, and rolling it with a ridge seeder. Tilled crops are tended with a row cultivator equipped with universal working bodies. The working bodies loosen the soil between rows, cut weeds, and hill cultivated plants by throwing loose soil of the required volume from the row spacings into the protective zones of the rows and the soil ridge.

The implementation of the proposed technological operations in the suggested sequence by the developed technical means will ensure the combination of several technological operations in one pass of the unit, reduce moisture loss from the soil, maintain soil fertility and increase the productivity of agricultural machines.

Production of farm produce contains certain technological operations, when they are implemented, the final product is obtained from the primary raw materials (seeds) using natural and anthropogenic energy.

Plants use natural energy (energy of the sun and energy of humus) in the process of photosynthesis to create biological mass.

Anthropogenic energy - energy received by a person from exhaustible sources and spent on the cultivation of agricultural crops, is divided into two types: energy of direct and indirect costs.

Direct costs include energy obtained from the combustion of liquid fuels and labor energy of workers.

Indirect (material) energy costs include energy costs for the manufacture of tractors, cars, agricultural machines, organic and mineral fertilizers, chemical products of plant protection, seed material, and energy spent on the extraction, processing and transportation of oil and raw materials for obtaining ferrous and non-ferrous metals, storage, and transportation of means of production.

In the general case, indirect costs are divided into two types: material and technical ones (depreciation), which function in agricultural production for a long time (fixed production assets) and transfer the energy costs embodied in them to produced products in parts during the entire service life, and circulating (sowing and planting material, fertilizers, plant protection chemicals), which transfer the energy contained in them to the products produced in one year (the vegetation period of the plant).

The information model of bioenergy flows during the cultivation of crop products is shown in Fig. 2.

It is possible to assess the energy efficiency of technology using the generalized indicator - the coefficient of the energy efficiency $k_{\ni \ni}$, which is calculated as a ratio of ener-

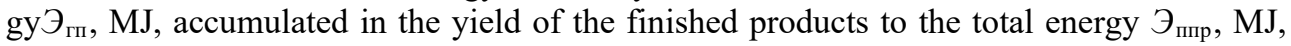
spent on its production:

$$
k_{\ni \ni}=\frac{Э_{\Gamma \Pi}}{Э_{\Pi \Pi Р}} .
$$

If $k_{\ni \ni}>1$, then the technology is considered justifiable in terms of energy use.

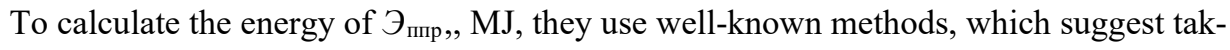


ing account of: solar energy and humus energy in natural energy costs; energy of material and technical resources and depreciation, expressed in energy equivalents, in indirect energy costs; energy required for the maintenance and repair of tractors, automobiles, combines and agricultural machines and energy for the extraction, processing and transportation of oil products in direct energy costs $[4,5,6,7,8,9]$.

However, the known methods for calculating the total energy consumption to produce crop products are imperfect due to the incorrect accounting of the energy spent on the manufacture of tractors, cars, combines, agricultural machines, fertilizers, and chemical plant protection products, since these energy costs are provided for by the manufacturers of these goods, and agricultural enterprises acquire these products of labor in the form of finished products. Therefore, these are financial costs, not energy costs. In addition, it is incorrect to take account of solar energy, since this energy is obtained without direct human participation, and it is free.

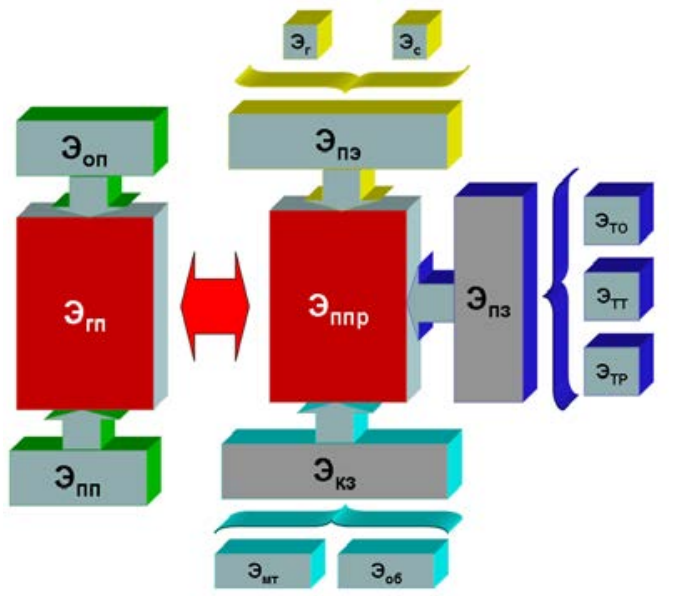

Fig. 2 Information model of bioenergy flows in crop production: $Э_{\text {гп }}-$ energy of finished products of crop production, MJ; $Э_{\text {пा }}$ - energy of crop by-products, $\mathrm{MJ}$; $Э_{\text {оп }}$ - energy of the main crop production, MJ; Э Эпр - energy for the production of crop products, MJ; Э Эп - natural energy, MJ; Эс - solar energy, MJ; Э $Э_{\Gamma}$ - energy of humus, MJ; $Э_{к з}$ - energy of indirect costs, MJ; $Э_{\mathrm{oy}}$ - energy of organic fertilizers, MJ; $Э_{\mathrm{му}}$ - energy of mineral fertilizers, MJ; $Э_{\mathrm{x}}$ - energy of chemical products of plant protection, MJ; Э $Э_{п з}-$ energy of direct costs, MJ; $Э_{\text {мт }}$ - energy of material and technical resources, MJ; Эоб - energy of circulating assets, MJ.

Based on the information presented above, it is advisable, when calculating the total anthropogenic energy, to consider in indirect costs only the energy of the source materials (seed, organic and mineral fertilizers, chemical products of plant protection) that directly influence the formation of the yield. 


\section{Analysis and discussion of results}

The general content of energy $Э_{\text {гп }}, \mathrm{MJ}$, accumulated in the yield of a crop:

$$
Э_{\text {гा }}=Э_{\text {оп }}+Э_{\text {пा }}=y_{\text {оп }} k_{\text {оп }} q_{\text {оп }}+Y_{\text {пा }} k_{\text {пा }} q_{\text {пा }},
$$

where $y_{\text {оп }}$ - the yield of the main crop, $\mathrm{kg} / \mathrm{ha} ; k_{\text {оп }}$ - conversion factor of basic products to dry matter; $q_{\text {оп }}-$ energy content in $1 \mathrm{~kg}$ of dry matter of the main product, $\mathrm{MJ} / \mathrm{kg} ; y_{\text {пा }}-$ the yield of crop by-product, $\mathrm{kg} / \mathrm{ha} ; k_{\mathrm{m}}$ - conversion factor of by-products to dry matter; $q_{\mathrm{m}}-$ energy content in $1 \mathrm{~kg}$ of dry matter of crop by-products, $\mathrm{MJ} / \mathrm{kg}$.

Energy $Э_{\Pi \Pi р}$, MJ, spent to produce a product in crop production:

$$
Э_{\Pi \Pi Р}=Э_{\Pi 3}+Э_{К з}+Э_{\Pi \ni}
$$

Direct energy costs in the cultivation of crops include the costs of energy obtained from the combustion of liquid fuel (diesel fuel or gasoline) and labor costs of the personnel:

$$
Э_{\text {пз }}=Э_{\text {то }}+Э_{\text {тТ }}+Э_{\text {тР }}
$$

where $\ni_{\mathrm{TO}}=\sum_{i=1}^{n} \ni_{\mathrm{TO} i}-$ total energy from fuel combustion spent on various technological operations (plowing, cultivation, harrowing, sowing, application of fertilizers, caring for crops, etc.), $\mathrm{MJ} ; \ni_{\mathrm{TT}}=\sum_{i=1}^{n} \ni_{\mathrm{TT} i}-$ total energy from fuel combustion spent on transportation of seeds, fertilizers, yield and etc., MJ; $\ni_{\mathrm{TP}}=\sum_{i=1}^{n} \ni_{\mathrm{TP} i}-$ the total energy of the personnel spent on various technological operations (plowing, cultivation, harrowing, sowing, transporting seeds, fertilizers, yield, application of fertilizers, caring for crops, etc.), MJ; $i-$ number of technological operations.

Energy, MJ, obtained from the combustion of liquid fuel and spent on a technological operation:

$$
Э_{\mathrm{TO} i}\left(\ni_{\mathrm{TT} i}\right)=H_{\mathrm{T}} \alpha_{\mathrm{T}},
$$

where $H_{\mathrm{T}}$ - amount of the fuel used up, $\mathrm{kg} / \mathrm{ha} ; \alpha_{\mathrm{T}}-$ fuel energy content, $\mathrm{MJ} / \mathrm{kg}$.

The energy equivalent of human labor is the cost of one man-hour in energy units, which depends on the share of personal consumption of the population relative to the gross domestic product (GDP), the specific power supply of human labor and the ratio between the real volumes of wages and energy resources, used in the branches of material production $[10,11]$.

Total energy, MJ, spent by workers in crop production: 


$$
\Im_{\mathrm{TP}}=\sum_{i=1}^{n} \Im_{\mathrm{TP} i},
$$

Then energy $Э_{\mathrm{TP}}, \mathrm{MJ} / \mathrm{ha}$, labor of workers spent on the implementation of one technological operation per unit of the field area:

$$
\Im_{\mathrm{TP} i}=e T_{\mathrm{p}},
$$

where $T_{\mathrm{p}}$ - labor intensity of the technological operation, person $\mathrm{h} / \mathrm{ha}$.

In accordance with the standards of the World Agrarian Organization (FAO), different categories of workers involved in the production of agricultural products consume different amounts of energy. Therefore, taking account of the GDP as the cost of newly spent labor and energy in the sphere of material production, we will establish an energy equivalent, $\mathrm{MJ} /($ person'hour), of labor per person [10]:

$$
e=\frac{\left(K-d n_{1}\right) c_{\mathrm{T}}}{d n_{2}}
$$

where $K=\left(c_{\mathrm{T}} T+O_{\phi \pi}\right) / c_{\mathrm{T}} T-$ coefficient; $d=\left(c_{\mathrm{T}} T+O_{\phi \pi}\right) /\left(n_{1} c_{\mathrm{T}} T+n_{2} c_{\ni} \ni\right)-$ share of the GDP intended for consumption; $n_{1}, n_{2}$ - share of human labor and energy in the sphere of material production; $c_{\mathrm{T}}, c_{\ni}$ - average cost of human labor and energy across the country; $T, \ni-$ annual amount of labor and energy expended; $O_{\text {фп }}$ - value of various consumption funds.

For example, energy equivalent of farm machinery operators is $60,8 \mathrm{MJ} /(\operatorname{man} \cdot \mathrm{h})$, drivers $-60,3 \mathrm{MJ} /(\operatorname{man} \cdot h)$, field workers $-33,3 \mathrm{MJ} /(\operatorname{man} \cdot \mathrm{h})[10,11]$.

By substituting expressions (5), (6) and (7) into expression (4), we determine the direct energy consumption in the production of crop products:

$$
Э_{\text {ПППР }}=\sum_{i=1}^{n}\left(H_{\text {Тто }} \alpha_{\mathrm{T}}\right)+\sum_{i=1}^{n}\left(H_{\text {Ттт }} \alpha_{\mathrm{T}}\right)+\sum_{i=1}^{n}\left(e T_{\mathrm{p}}\right) .
$$

Energy, MJ, of indirect costs should include energy of the seed material, fertilizers, and plant protection chemicals:

$$
Э_{\mathrm{K} 3}=Э_{\mathrm{K} 3 \mathrm{c}}+Э_{\mathrm{K} 3 \mathrm{y}}+Э_{\mathrm{K} 3 \mathrm{x}} \text {. }
$$

The transfer of indirect energy of indirect materials to the final product is carried out based on the seeding rate (application) of the initial material and its validity period:

- seed material

$$
Э_{\mathrm{K} 3 \mathrm{c}}=\alpha_{\mathrm{c}} H_{\mathrm{c}},
$$

- organic (mineral) fertilizers

$$
Э_{\text {кзу }}=\frac{\alpha_{\mathrm{y}} H_{\text {у }} k_{\text {исп }}}{T_{\mathrm{y}}},
$$

- plant protection chemicals 


$$
\ni_{\text {Кзх }}=\frac{\alpha_{\mathrm{x}} H_{\mathrm{x}} k_{\text {исп }}}{T_{\mathrm{x}}},
$$

where $\alpha_{\mathrm{c}}$ - energy equivalent of seed, $\mathrm{MJ} / \mathrm{kg} ; \alpha_{0}$ - energy equivalent of fertilizers (organic, mineral), MJ $/ \mathrm{kg} ; \alpha_{\mathrm{x}}$ - energy equivalent of plant protection chemicals, $\mathrm{MJ} / \mathrm{kg} ; H_{\mathrm{c}}$ - sowing rate, $\mathrm{kg} / \mathrm{ha} ; H_{\mathrm{y}}$ - fertilization rate, $\mathrm{kg} / \mathrm{ha} ; H_{\mathrm{x}}$ - application rate of plant protection chemicals, $\mathrm{kg} / \mathrm{ha} ; k_{\text {исп }}-$ coefficient of substance utilization by crops; $T_{\mathrm{y}}-$ period of the effect of fertilizers (after-effect), years; $T_{\mathrm{x}}$ - period of the effect of plant protection chemicals, years.

Substituting expressions (11), (12), (13) into expression (10), and expressions (9) and (10) into expression (3), we determine the total energy spent in the production of crop products:

$$
\begin{gathered}
\Im_{\text {mip }}=\sum_{i=1}^{n}\left(H_{\text {Tто }} \alpha_{\mathrm{T}}\right)+\sum_{i=1}^{n}\left(H_{\text {Ттт }} \alpha_{\mathrm{T}}\right)+\sum_{i=1}^{n}\left(e T_{\mathrm{p}}\right)+\alpha_{\mathrm{c}} H_{\mathrm{c}}+ \\
+\frac{\alpha_{\mathrm{y}} H_{\mathrm{y}} k_{\text {nеп }}}{T_{\mathrm{y}}}+\frac{\alpha_{\mathrm{x}} H_{\mathrm{x}} k_{\text {исп }} .}{T_{\mathrm{x}}} .
\end{gathered}
$$

From expression (14) it follows that the energy to produce crop products depends on the energy obtained from the combustion of liquid fuel, the energy of the live labor of the personnel, the energy of the seed material, as well as the energy from the use of fertilizers and plant protection chemicals.

Application of the proposed methodology will make it possible to assess adequately the energy efficiency of crop production, considering the energy of direct and indirect costs.

In comparison with the traditional technology of row crop cultivation on a flat surface of the field, with the proposed ridge technology, the yields of soybeans, sunflower and corn increased on average over 5 years by 20,16 and $38 \%$, respectively.

The energy efficiency of technologies for the cultivation of row crops is presented in

\begin{tabular}{|c|c|c|c|c|c|}
\hline \multicolumn{2}{|c|}{$\begin{array}{l}\text { Energy with the use of tradi- } \\
\text { tional technology }\end{array}$} & \multicolumn{2}{|c|}{$\begin{array}{l}\text { Energy with the use of ridge } \\
\text { technology }\end{array}$} & \multicolumn{2}{|c|}{ Energy efficiency coefficient $k$ ээ } \\
\hline $\begin{array}{c}Э_{\text {гп }}, \\
\mathrm{MJ} / \mathrm{ha}\end{array}$ & $\begin{array}{l}Э_{\text {пाр }}, \\
\mathrm{MJ} / \mathrm{ha}\end{array}$ & $\begin{array}{c}Э_{\mathrm{rn}}, \\
\mathrm{MJ} / \mathrm{ha}\end{array}$ & $\begin{array}{l}Э_{\text {ппр }} \\
\mathrm{MJ} / \mathrm{ha}\end{array}$ & $\begin{array}{c}\text { traditional tech- } \\
\text { nology }\end{array}$ & $\begin{array}{c}\text { ridge } \\
\text { technology }\end{array}$ \\
\hline \multicolumn{6}{|c|}{ Corn for grain } \\
\hline 90713 & 8150 & 119438 & 7683 & 11,13 & 15,54 \\
\hline \multicolumn{6}{|c|}{ Sunflower } \\
\hline 28527 & 4840 & 44574 & 4590 & 5,9 & 9,71 \\
\hline \multicolumn{6}{|c|}{ Soybeans } \\
\hline 17456 & 6168 & 20365 & 5935 & 2,83 & 3,43 \\
\hline
\end{tabular}
Table 1.

Table 1. Energy efficiency of row crop cultivation technology

Having analyzed the data of Table 1, we can conclude that the practical implementation of ridge technology in comparison with the traditional one gives an opportunity to reduce energy $Э_{\text {ппр }}$, MJ, spent on row crop cultivation by $233 . .467 \mathrm{MJ} / \mathrm{ha}$. In addition, due to 
the ensured increase in the yield energy in the grain is accumulated by $2909 \ldots 28725 \mathrm{MJ} / \mathrm{ha}$ more.

\section{Conclusion}

The use of the devised energy-saving, resource-saving ridge technology for row crop cultivation and means of mechanization to implement this technology makes it possible to increase the yield of row crops on average in 5 years up to $38 \%$ without the use of environmentally unsafe herbicides.

The application of ridge technology of cultivation of corn for grain, sunflower and soybeans, the coefficients of energy efficiency, respectively, amounted to $15.54 ; 9.71$ and 3.43 units, which is by $0.6 ; 3.81$ and 4.41 units more in comparison with the traditional technology of cultivation of the above-mentioned crops on a flat surface of the field.

\section{References}

1. Zykin, E.S. Development and substantiation of technology and means of mechanization of ridge cultivation of row crops: specialty code 05.20.01 - Technologies and means of agricultural mechanization: dissertation ... Doctor of Technical Sciences / Zykin Evgeny Sergeevich (Ufa). - Ulyanovsk, 2017.- 637 p.

2. Kurdyumov, V.I. Energy-saving means of mechanization of ridge cultivation of row crops / V.I. Kurdyumov, E.S. Zykin // Bulletin of the Ulyanovsk State Agricultural Academy. - 2013. - No. 1 (21). - pp. 144 - 149.

3. Kurdyumov, V.I. Justification of the position of the working bodies with flat disks along the width of the ridge seeder gang / V.I. Kurdyumov, E.S. Zykin // Bulletin of the Ulyanovsk State Agricultural Academy. - 2014. - No. 3 (27). - pp. 116 - 120.

4. Gordeyev, A.S. Energy saving in agriculture / A.S. Gordeyev, D.D. Ogorodnikov, I.V. Yudaev. - S-Pb .: Publishing house "Lan", 2014. - 400 p.

5. Rabochev, G.I. Bioenergetic assessment of technological processes in crop production / G.I. Rabochev, V.G. Kutilkin, A.L. Rabochev. - Samara, 2004.- 112 p.

6. Bulatkin, G.A. Ecological and energy foundations of optimizing the productivity of agroecosystems / G.A. Bulatkin. - M .: NIA-Priroda, 2008.- 366 p.

7. Bazarov, E.I. Methodology for bioenergetic assessment of crop production technologies / E.I. Bazarov, E.V. Glinka, A.A. Mamontova. - M .: VASKhNIL, 1983 .- 44 p.

8. Kurdyumov, V.I. Optimization of parameters and operating modes of the coulter for seeding seeds and fertilizers at different depth levels / V.I. Kurdyumov, E.S. Zykin, G.L. Tatarov // Bulletin of the Ulyanovsk State Agricultural Academy. - 2015. - No. 4 (31). - pp. 195-200. 
9. Kurdyumov, V.I. Justification of the distance between flat discs of a row cultivator / V.I. Kurdyumov, E.S. Zykin, S.A. Lazutkina // Bulletin of the Ulyanovsk State Agricultural Academy. - 2016. - No. 3 (35). - pp. 174 - 178.

10. Shchelokov, Ya.M. Energy analysis of economic activities. Energy problems of energy-intensive industries. - Yekaterinburg: Academy of Engineering Sciences named after A.M. Prokhorov, 2010 . - 388 p.

11. 11.GOST R 51750-2001. Methodology for determining energy consumption in the production of products and the provision of services in technological energy systems. - Introduction. 2001-05-21. - M .: Publishing house of standards. - 60 p. 